\title{
ANALISIS PENGGUNAAN ENERGI LISTRIK MOTOR INDUKSI TIGA PHASA MENGGUNAKAN VARIABLE SPEED DRIVE (VSD)
}

\author{
Atmam $^{1}$, Abrar Tanjung ${ }^{2}$, Zulfahri $^{3}$ \\ 1,2,3 Program Studi Teknik Elektro, Fakultas Teknik, Universitas Lancang Kuning \\ Jl. Yos Sudarso km. 8 Rumbai, Pekanbaru, Telp. (0761) 52324 \\ Email : atmam@unilak.ac.id, abrar@unilak.ac.id, zulfahri@unilak.ac.id
}

\begin{abstract}
ABSTRAK
Motor induksi tiga phasa banyak digunakan sebagai penggerak peralatan dengan kecepatan penuh atau relatif konstan. Konsumsi daya pada motor induksi dengan kecepatan konstan lebih besar, hal tersebut menyebabkan pemborosan energi listrik. Untuk mengatasi permasalahan tersebut dibutuhkan suatu cara untuk menghemat energi listrik. Salah satu cara untuk menghemat pemakaian energi listrik pada pengoperasian motor induksi tiga phasa adalah menggunakan Variable Speed Drive (VSD). Dari hasil penelitian ini diperoleh daya motor induksi tiga phasa bila dioperasikan tanpa menggunakan VSD sebesar 0,479 kW dengan energi listrik sebesar 0,479 kWH dan motor induksi menggunakan VSD sebesar 0,330 kW dengan energi listrik sebesar $0,330 \mathrm{kWh}$. Perbandingan penggunaan energi listrik motor induksi tiga phasa menggunakan VSD lebih rendah sebesar $0,149 \mathrm{kWh}$ dibandingkan tanpa VSD dengan penghematan energi listrik sebesar $31,10 \%$ atau sebesar Rp. 6.043,44 dalam satu bulan.
\end{abstract}

Kata Kunci : Motor induksi tiga phasa, variable speed drive, energi

\section{ABSTRACT}

Three-phase induction motors are widely used to drive equipment at full or relative speed. Power consumption on an induction motor with a constant velocity is greater, thus causing a waste of electrical energy. To overcome these problems needed a way to save electrical energy. One way to save electricity usage on the operation of three phase induction motor is to use Variable Speed Drive (VSD). From the results of this study obtained three-phase induction motor power when operated without using VSD of $0.479 \mathrm{~kW}$ with electrical energy of $0.479 \mathrm{kWH}$ and induction motor using VSD of $0.330 \mathrm{~kW}$ with electrical energy of 0.330 $\mathrm{kWh}$. Comparison of electric energy use of three phase induction motor using VSD lower by 0,149 $\mathrm{kWh}$ than without VSD with electric energy saving equal to 31,10\% or equal to Rp. 6,043.44 in one month.

Keywords: Three phase induction motor, variable speed drive, energy

\section{PENDAHULUAN}

Motor induksi banyak digunakan di industri dan rumah tangga karena motor induksi tersebut mempunyai konstruksi sederhana, mudah dioperasikan, relatif lebih murah dalam perawatannya. Sarhan (2011) menyatakan bahwa diperkirakan lebih dari 50\% energi listrik dunia yang dihasilkan dikonsumsi oleh mesin listrik.

Adapun jenis motor induksi saat pengoperasiannya dengan sumber tegangan yang diberikan salah satunya adalah jenis motor induksi tiga phasa. Motor induksi tiga phasa sering digunakan sebagai penggerak pada peralatan dengan kecepatan penuh atau kecepatan yang relatif konstan. Konsumsi daya pada motor induksi dengan kecepatan konstan lebih besar dan hal tersebut dapat menyebabkan pemborosan energi listrik. Untuk mengatasi permasalahan tersebut, maka dibutuhkan suatu cara untuk menghemat energi listrik, khususnya dalam pengoperasian motor listrik. Salah satu upaya adalah dengan menggunakan Variable Speed Drive (VSD) atau dapat disebut juga dengan Variable Frequency Drive (VFD).

Variable speed drive atau variable frekuensi drive adalah suatu alat yang digunakan untuk mengendalikan kecepatan motor listrik (AC) dengan mengontrol frekuensi daya listrik yang dipasok ke motor. Pada perangkat tersebut terdapat rectifier, inverter dan microcontroller [1].

Selain itu, penggunaan motor induksi saat ini masih banyak menggunakan cara konvensional yaitu menggunakan sistem starting secara langsung (direct-on-line) atau langsung dihubungkan pada sumber listrik. Penggunaan cara ini akan menimbulkan arus start yang tinggi pada motor induksi sehingga dapat juga menyebabkan pemborosan energi listrik.

Dari uraian di atas, maka untuk melihat penggunaan energi listrik pada pengoperasian motor 
induksi tiga phasa menggunakan Variable Speed Drive (VSD) maka diperlukan penelitian. Pada penelitian ini, untuk menganalisa penggunaan energi listrik pada motor induksi tiga phasa adalah dalam kondisi tanpa menggunakan Variable Speed Drive (VSD) dan menggunakan Variable Speed Drive (VSD).

\section{METODE PENELITIAN}

Metode penelitian yang digunakan dalam penelitian ini adalah :

\section{Metode pengumpulan data}

Metode yang digunakan pada proses pengumpulan data yaitu metode eksperiment yaitu dari objek yang diteliti yaitu motor induksi tiga phasa 0,5 HP, 380 Volt, $50 \mathrm{~Hz}, 1400 \mathrm{rpm}$, dengan melakukan percobaan dan pengukuran untuk mendapatkan data-data pada pengukuran arus, daya dan faktor daya motor induksi tiga phasa motor tanpa VSD, serta pengukuran arus, daya dan faktor daya motor induksi tiga phasa motor dengan VSD.

\section{Metode Pengolahan data}

Dari data yang diperoleh dari percobaan dan pengukuran motor induksi tiga phasa tanpa VSD dan dengan VSD diperoleh nilai arus, daya dan faktor daya motor induksi tiga phasa dan data-data tersebut digunakan untuk menghitung penggunaan energi listrik.

\section{Analisis data}

Dari data yang telah diolah maka selanjutnya dilakukan analisa data untuk mendapat nilai daya dan energi listrik motor induksi tiga phasa tanpa VSD dalam rentang waktu tertentu, menganalisa motor induksi tiga phasa menggunakan VSD untuk menentukan nilai daya dan energi listrik dalam rentang waktu tertentu dengan VSD dan membandingkan penggunaan energi listrik saat kondisi motor induksi tiga phasa yaitu energi listrik tanpa VSD dibandingkan dengan energi listrik menggunakan VSD.

Umumnya motor induksi dikenal ada dua macam berdasarkan jumlah fasa yang digunakan, yaitu: motor induksi satu fasa dan motor induksi tiga fasa. Sesuai dengan namanya motor induksi satu fasa dirancang untuk beroperasi menggunakan suplai tegangan satu fasa dan motor induksi tiga fasa dengan suplai tegangan tiga fasa. Motor induksi sering digunakan sebagai penggerak pada peralatan dengan kecepatan yang relatif konstan. Hal ini disebabkan karena motor induksi satu fasa memiliki beberapa kelebihan yaitu konstruksi yang cukup sederhana, kecepatan putar yang hampir konstan terhadap perubahan beban (Atmam, 2017). Motor induksi (IM) banyak digunakan dalam banyak aplikasi, biaya rendah, torsi yang baik, dan tahan [3].

Analisis energi listrik merupakan upaya untuk mengoptimalkan kerja peralatan kondisi beban penuh sehingga penggunaan energi listrik menjadi lebih efektif, efisien dan rasional tanpa harus mengurangi kinerja produksi dengan menggunakan VSD (Variable Speed Drive) yang berguna sebagai pengatur kecepatan motor induksi [4]. Ada beberapa cara yang dapat dilakukan untuk mengendalikan kecepatan putar motor induksi tersebut di antaranya dengan kendali tegangan dan frekuensi yang dikenal dengan kendali V/f konstan. Kendali V/f konstan adalah salah satu cara untuk mengendalikan kecepatan putar motor induksi dengan merubah tegangan dan frekuensi, tetapi menjaga konstan rasio keduanya. Sehingga dengan cara kendali ini, torsi yang dihasilkan dapat dijaga konstan sepanjang daerah pengaturan kecepatan. Hal yang paling umum dalam penerapan cara ini adalah dengan menggunakan perangkat yang dikenal sebagai inverter [5].

Kebutuhan akan kecepatan variabel motor induksi ac muncul dalam aplikasi industri tertentu dan ini seringkali sulit dicapai karena motor induksi memiliki kecepatan tetap. Hasil penelitian memperlihatkan bahwa untuk mencapai kontrol kecepatan motor induksi dari nol ke kecepatan nominal dengan memvariasikan frekuensi tegangan ac yang diberikan dengan menggunakan metode modulasi lebar pulsa [6]. Penggunaan Variable Speed Drive (VSD) untuk pengaturan motor fuel screw feeder untuk bahan bakar pada sistem boiler. Hasil penelitian memperlihatkan bahwa putaran motor divariasikan pada $300 \mathrm{rpm}$ - $1500 \mathrm{rpm}$ menggunakan Variable Speed Drive (VSD) untuk pengaturan aliran batu bara [7].

Pengaturan kecepatan motor induksi tiga fasa dapat dilakukan dengan berbagai cara salah satunya adalah dengan menggunakan Variable Speed Drive yang berfungsi mengatur frekuensi sumber sehingga mendapatkan kecepatan (rpm) motor yang diinginkan. Hasil yang didapatkan adalah motor induksi tiga fasa dapat diatur kecepatannya dengan alat Variable Speed Drive (Inverter) dengan rentang pengaturan yang sangat luas mulai dari $0-50 \mathrm{~Hz}$ [8]. Banyak industri dengan pertumbuhan terbesar di dunia dan juga perusahaan sektor listrik mengatakan bahwa sekitar 30\% listrik dikonsumsi di seluruh dunia untuk penerapan pendinginan dan pengkondisian udara. Energi adalah kebutuhan yang tak terelakkan bagi penghuni dunia modern. Dalam kasus seperti itu, energi yang tidak diinginkan harus disimpan dalam cold storage. Penyiapan eksperimental dirancang menggunakan VFD dan tanpa VFD dan hasilnya ditampilkan untuk membuktikan konsep penghematan energi pada cold storage [9]. Pengontrolan kecepatan motor induksi 
menggunakan Variable Frequency Drive (VFD). Variable Frequency Drive (VFD) adalah sebuah peralatan elektronik yang dapat mengubah sumber dengan frekuensi variabel untuk mengontrol motor AC pada pengoperasian variabel. Beban dari motor induksi tidaklah konstan bisa naik dan turun. Dengan menggunakan Variable Frequency Drive (VFD) maka kecepatan motor dapat diatur dengan mengatur frekuensi suplai [1]

Inverter listrik adalah konverter daya listrik yang mengubah arus searah (DC) menjadi arus bolakbalik (AC). Tegangan masukan, tegangan keluaran, dan frekuensi tergantung pada desain yang dirancang. Dalam dunia kelistrikan inventer memang sangat populer digunakan dalam berbagai keperluan. Inverter adalah suatu alat yang dapat mengubah tegangan bolak-balik menjadi tegangan searah dengan frekuensi dan tingkat tegangan yang dapat diatur [10]. Inverter dapat secara luas diklasifikasikan ke dalam dua tipe, yaitu inverter satu fasa dan inverter tiga fasa. Setiap tipe inverter ini dapat menggunakan piranti terkendali turn-on dan turn-off (seperti BJTT, MOSFET, IGBT, MCT, SIT, GTO) atau tyristror komutasi paksa tergantung pada aplikasinya.

\section{Variabel Speed Drive (VSD)}

Variabel speed drive atau variabel frekuensi drive adalah suatu alat yang digunakan untuk mengendalikan kecepatan motor listrik (AC) dengan mengontrol frekuensi daya listrik yang dipasok ke motor. Variabel frekuensi drive semakin popular karena kemampuannya untuk mengontrol kecepatan motor induksi. VSD mengontrol kecepatan motor induksi dengan mengubah frekuensi dari grid untuk nilai disesuaikan pada sisi mesin sehingga memungkinkan motor listrik dengan cepat dan mudah menyesuaikan kecepatan dengan nilai yang diinginkan.

Dua fungsi utama dari variabel frekuensi drive adalah untuk melakukan konversi listrik dari satu frekuensi ke yang lain, dan untuk mengontrol frekuensi keluaran. Aplikasi VSD digunakan dari mulai peralatan kecil sampai peralatan besar, yaitu pengaturan pabrik tambang, kompresor dan sistem ventilasi untuk bangunan besar. Selain itu VSD juga digunakan pada pompa, konveyor dan alat pengendali mesin. Penggunaan variabel frekuensi drive pada motor dapat menghemat energi sehingga mengurangi biaya listrik.

Bentuk rangkaian dari Variabel speed drive (VSD) terdiri dari beberapa bagian seperti rectifier, DC link, dan Inverter. Rangkaian dari Variabel speed drive (VSD) seperti pada gambar 1 .

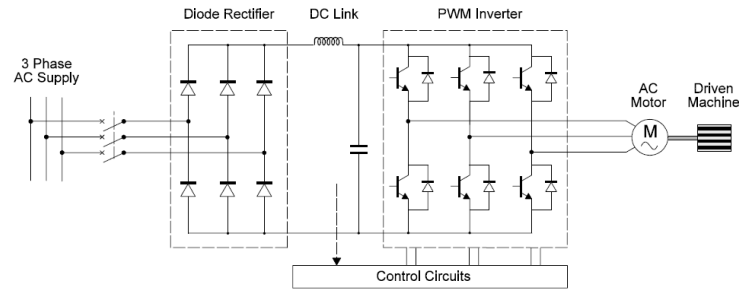

Gambar 1. Rangkaian Variable Speed Drive (VSD)

\section{Rectifier atau Penyearah}

Penyearah gelombang penuh dengan trafo tap dan penyearah sistem jembatan ditunjukkan pada Gambar 1 dan 2 [10].

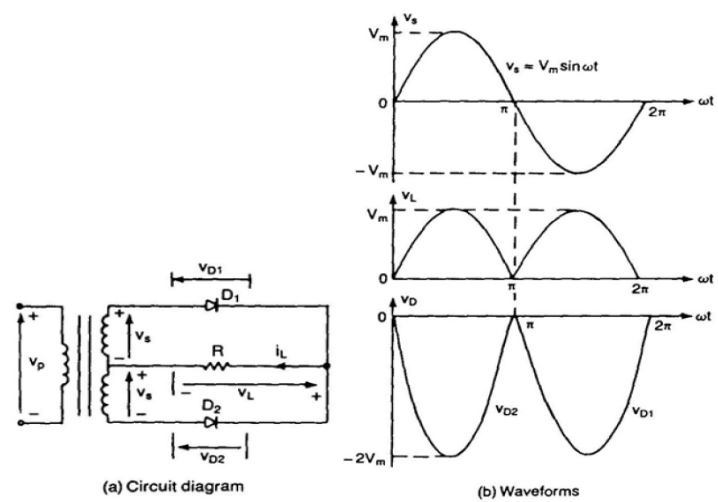

Gambar 1. Penyearah gelombang penuh satu phasa dengan trafo tap

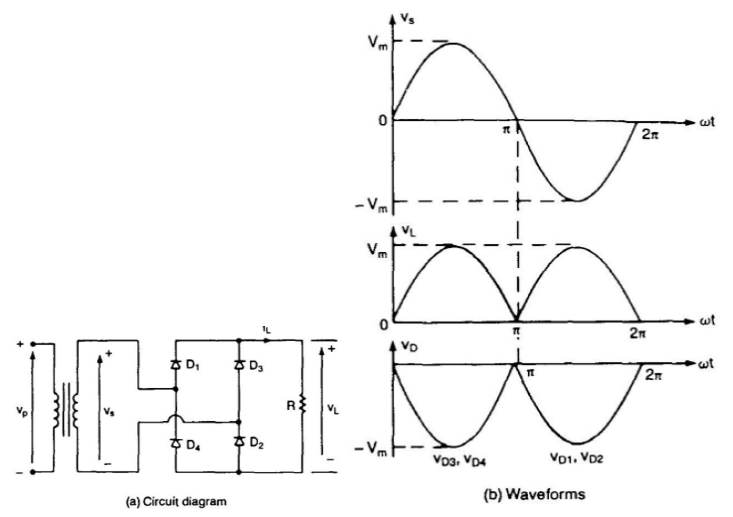

Gambar 2. Penyearah gelombang penuh satu phasa jembatan

Tegangan pada beban resistif untuk penyearah jembatan pada Gambar 1 dinyatakan sebagai [11]:

$$
v_{o}(\omega t)= \begin{cases}V_{m} \sin \omega t & \text { for } 0 \leq \omega t \leq \pi \\ -V_{m} \sin \omega t & \text { for } \pi \leq \omega t \leq 2 \pi\end{cases}
$$

Tegangan keluaran $\mathrm{V}_{\mathrm{dc}}$ dan arus $\mathrm{I}_{\mathrm{dc}}$ rata-rata dari penyearah gelombang penuh satu phasa adalah sebagai berikut [11]: 


$$
\begin{aligned}
& V_{o}=\frac{1}{\pi} \int_{0}^{\pi} V_{m} \sin (\omega t) d \omega t=\frac{2 V_{m}}{\pi} \\
& I_{o}=\frac{V_{o}}{R}=\frac{2 V_{m}}{\pi \times R}
\end{aligned}
$$

Tegangan dan arus keluaran rms dari rectifier gelombang penuh satu phasa ditulis dengan menggunakan persamaan [10] :

$$
\begin{aligned}
V_{d c-r m s} & =\left[\frac{2}{T} \int_{0}^{T / 2}\left(V_{m} \sin (\omega t)^{2} d t\right)\right]^{1 / 2} \\
& =\frac{V_{m}}{\sqrt{2}}=0,707 \times V_{m} \\
I_{d c-r m s} & =\frac{V_{r m s}}{R}=\frac{0,707 \times V_{m}}{R}
\end{aligned}
$$

\section{Inverter}

Inverter adalah rangkaian konverter yang berfungsi mengubah tegangan DC menjadi tegangan AC dengan switching. Komponen semikonduktor daya yang digunakan dapat berupa SCR, transistor, dan mosfet yang beroperasi sebagai saklar dan pengubah. Aplikasi dari inverter dapat dijumpai pada power supply, un-interruptible power supply (UPS), industrial (induction motor) drives, active filter, HVDC dan lain-lain. Blok diagram dari suatu inverter adalah seperti gambar 3 .

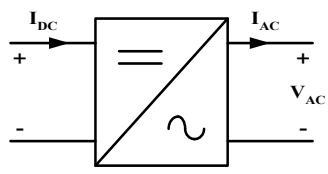

Gambar 3. Blok diagram inverter

Tegangan input dari inverter adalah tegangan DC murni (tanpa ripple) seperti gambar 4. Output dari inverter berupa tegangan $\mathrm{AC}$ dan dikelompokan menjadi tiga bentuk gelombang yaitu square-wave (gelombang kotak), pulse width modulation (PWM) dan sinusoidal. Adapun bentuk dari tiap-tiap gelombang dari output inverter seperti pada gambar 5 .

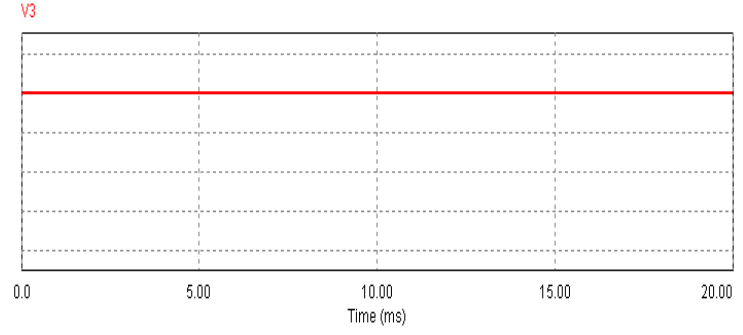

Gambar 4. Tegangan input inverter

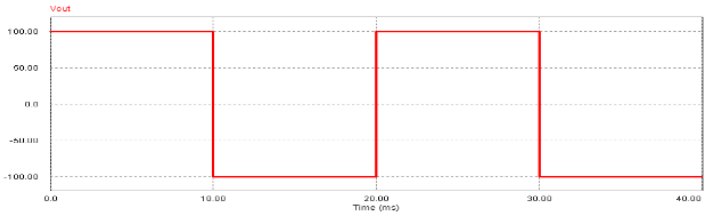

(a) Square-wave

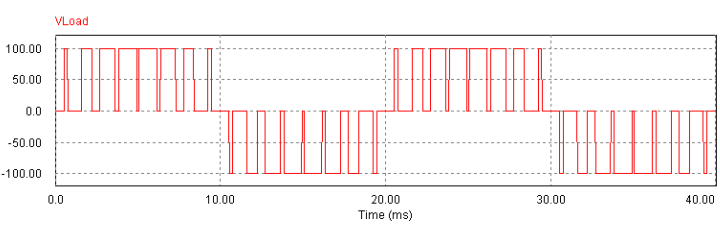

(b) PWM

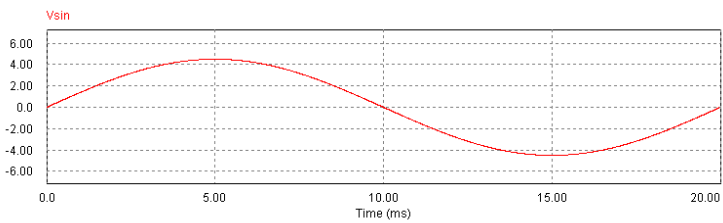

(c) Sinusoidal

Gambar 5. Gelombang output inverter [2]

\section{Energi dan Daya Listrik}

Energi listrik adalah sejumlah daya listrik yang diserap selama waktu tertentu. Energi listrik diukur dengan menggunakan alat ukur listrik yang disebut dengan wattjam meter atau $\mathrm{kWh}$ meter atau $\mathrm{MWh}$ meter. Satuan energi listrik sebagai berikut : watt detik, wattjam, kilo Watt jam (kWh), Mega Watt jam (MWh). Energi listrik dituliskan dengan persamaan :

$$
W=P \times t
$$

Keterangan:

$$
\begin{aligned}
W & =\text { Energi Listrik (Wh) } \\
P & =\text { daya (Watt) } \\
t & =\text { waktu }
\end{aligned}
$$

Daya adalah suatu gaya yang menyebabkan sesuatu benda dapat bergerak atau jumlah kerja yang dapat dilakukan dalam satuan waktu dan diberi dengan simbol P dengan satuan watt atau Joule/detik dan dituliskan dengan persamaan sebagai berikut :

$$
P=V \times I
$$

Keterangan:

$P=$ daya (Watt)

$V=$ tegangan (Volt)

$I=$ arus (Amper)

Perhitungan daya pada motor induksi tiga phasa dapat dihitung dengan menggunakan perhitungan :

$$
P=\sqrt{3} \times V \times I \times \operatorname{Cos} \varphi
$$




\section{HASIL DAN PEMBAHASAN}

Data motor induksi satu phasa dari data name plate yang diteliti adalah sebagai berikut :

$$
\begin{array}{ll}
\text { Daya Motor } & : 0,5 \mathrm{HP}(0,37 \mathrm{~kW}) \\
\text { Jumlah Kutub } & : 4 \\
\text { Frekuensi } & : 50 \mathrm{~Hz} \\
\text { Tegangan } & : 380 \mathrm{Volt} \\
\text { Arus } & : 1,16 \mathrm{Amper} \\
\text { Putaran } & : 1400 \mathrm{rpm}
\end{array}
$$

Untuk data inverter berupa Variable Speed Drive (VSD) sebagai berikut :

$\begin{array}{ll}\text { Series } & : \text { ATV320 } \\ & \text { (ATV320U07N4C) } \\ \text { Power (kW) } & : 0,75(1 \mathrm{HP}) \\ \text { Phases } & : \text { Three Phase } \\ \text { Voltage input (Volt) } & : 380-480 \mathrm{~V} \\ \text { Voltage output (Volt) } & : 380-480 \mathrm{~V} \\ \text { Frequency (Hz) input } & : 50 / 60 \\ \text { Frequency (Hz) output } & : 0 \ldots 599 \\ \text { Current input (Amps) } & : 3,6 \text { max } \\ \text { Current output (Amps) } & : 2,3\end{array}$

Pada penelitian ini, pengujian motor induksi tiga phasa sebagai kipas angin dilakukan tanpa VSD dan menggunakan VSD. Berikut adalah model motor induksi tiga phasa suplai tanpa VSD dan dengan VSD seperti gambar 6 .

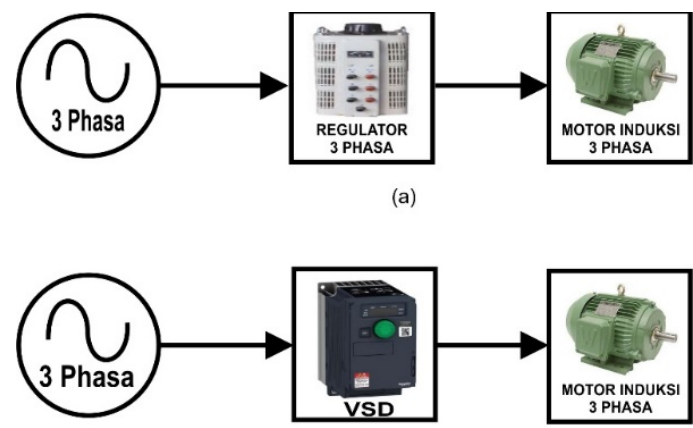

(b)

Gambar 6. Diagram blok pengoperasian motor induksi tiga phasa (a) tanpa VSD (b) menggunakan VSD

Selanjutnya pada penelitian ini dilakukan pengambilan data melalui percobaan dan pengukuran tegangan, arus, daya dan energi listrik motor induksi tiga phasa tanpa menggunakan VSD seperti pada tabel 1. Adapun hasil pengukuran motor induksi tiga phasa dengan menggunakan VSD diperlihatkan pada tabel 2.

Tabel 1. Hasil pengukuran tegangan, arus, daya dan energi listrik motor induksi tiga phasa tanpa VSD

\begin{tabular}{ccccccc}
\hline Tanggal & Waktu & $\begin{array}{c}\text { Tegangan } \\
(\text { Volt })\end{array}$ & $\begin{array}{c}\text { Arus } \\
(\text { Amper })\end{array}$ & Cos phi & $\begin{array}{c}\text { Total Daya } \\
(\mathrm{P}) \\
(\mathrm{kW})\end{array}$ & $\begin{array}{c}\text { Total Energi } \\
\text { Listrik } \\
(\mathrm{kWH})\end{array}$ \\
\hline \multirow{3}{30/01/2018}{} & $\begin{array}{c}13: 28: 05 \\
\mathrm{~s} / \mathrm{d} \\
14: 28: 04\end{array}$ & 376 & 0,996 & 0.74 & 0.479 & 0,479 \\
\hline
\end{tabular}

Tabel 2. Hasil pengukuran tegangan, arus, daya dan energi listrik motor induksi tiga phasa menggunakan VSD

\begin{tabular}{ccccccc}
\hline Tanggal & Waktu & $\begin{array}{c}\text { Tegangan } \\
(\text { Volt })\end{array}$ & $\begin{array}{c}\text { Arus } \\
(\text { Amper })\end{array}$ & Cos phi & $\begin{array}{c}\text { Total Daya } \\
(\mathrm{P}) \\
(\mathrm{kW})\end{array}$ & $\begin{array}{c}\text { Total Energi } \\
\text { Listrik }(\mathrm{kWH})\end{array}$ \\
\hline \multirow{3}{*}{$30 / 01 / 2018$} & $\begin{array}{c}17: 24: 39 \\
\mathrm{~s} / \mathrm{d} \\
18: 24: 37\end{array}$ & 387 & 0,987 & 0.5 & 0.330 & 0,330 \\
\hline
\end{tabular}

\section{Daya dan energi listrik motor induksi tiga phasa tanpa VSD.}

Daya dan pemakaian energi listrik motor induksi tiga phasa dapat dihitung dengan menggunakan data pada tabel 1 dan hasilnya sebagai berikut :

$$
\begin{aligned}
P & =\sqrt{3} V \times I \times \operatorname{Cos} \varphi \\
& =\sqrt{3} 376 \times 0,996 \times 0,74 \\
& =479,99 \mathrm{Watt} \\
& =0,479 \mathrm{~kW}
\end{aligned}
$$


Pemakaian energi listrik selama 1 (satu) jam dari 1 (satu) buah motor induksi tiga phasa sebagai kipas angin sebagai berikut :

$$
\begin{aligned}
W & =0,479 \mathrm{~kW} \times 1 \mathrm{jam} \\
& =0,479 \mathrm{kWh}
\end{aligned}
$$

Hasil perhitungan untuk pemakaian energi listrik dari motor induksi tiga phasa selama 1 (satu) jam tanpa VSD maka diperoleh pemakaian energi listrik sebesar $0,479 \mathrm{kWh}$. Hasil pengukuran daya motor induksi satu fasa diperoleh grafik daya dari motor induksi seperti pada gambar 7 .

Dari Gambar 7, motor induksi tiga phasa dioperasikan selama 1 (satu) jam dan daya yang terjadi berfluktuatif yang disebabkan oleh perubahan tegangan input yang diberikan pada motor induksi tiga phasa. Selanjutnya hubungan antara pemakaian energi listrik dari motor induksi tiga phasa seperti pada gambar 8 dan dalam rentang waktu mulai startingnya motor induksi tiga phasa, maka pemakaian energi listrik terus meningkat dimana pada rentang waktu 1 (satu) jam konsumsi energi listrik sebesar $0,479 \mathrm{kWh}$ yang diuji pada tanggal 30 Januari 2018.

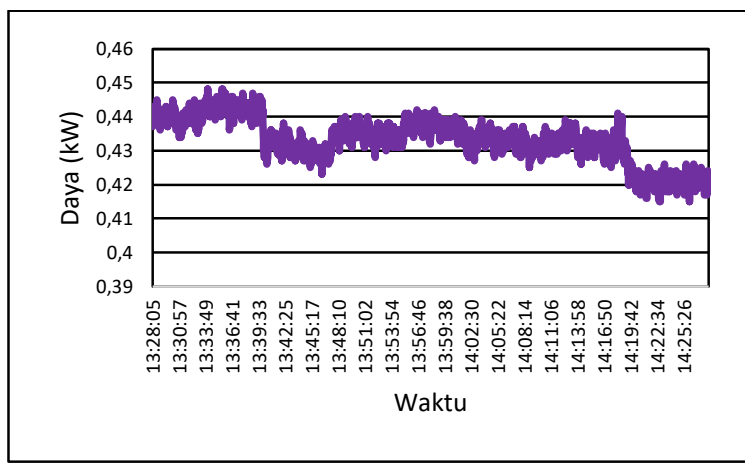

Gambar 7. Grafik daya motor induksi tiga phasa tanpa VSD

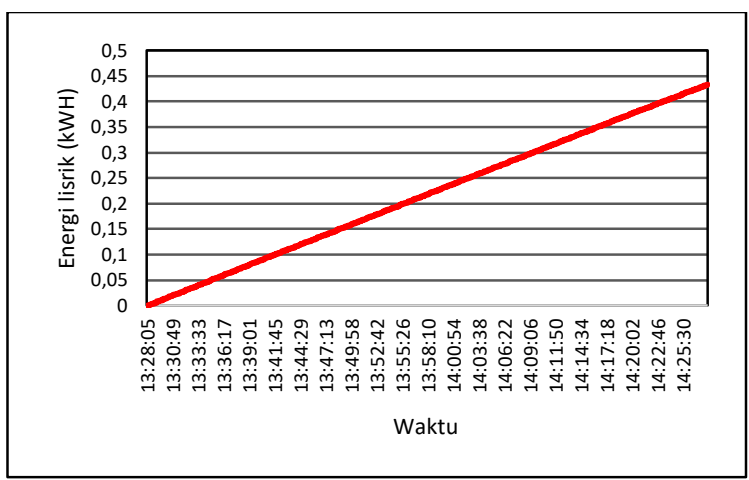

Gambar 8. Grafik pemakaian energi listrik pada motor induksi tiga phasa tanpa VSD
Perhitungan biaya pemakaian energi listrik motor induksi tiga phasa sebagai kipas angin tanpa VSD bila biaya per-kWh energi listrik sebesar Rp. 1.352,(Kementerian ESDM, 2016), maka diasumsikan sebagai berikut :

Pemakaian selama satu (1) jam dalam sehari

Biaya energi listrik $=0,479 \mathrm{~kW} \times 1$ jam $\times$ Rp.1.352,$=\operatorname{Rp}$.647.608,-

Untuk pemakaian satu bulan maka biaya energi listrik adalah :

30 hari $x$ Rp. $586,768=$ Rp. $19.428,24$

\section{Daya dan energi listrik motor induksi tiga phasa menggunakan VSD.}

Daya dan pemakaian energi listrik motor induksi tiga phasa sebagai kipas angin dapat dihitung dengan menggunakan data pada tabel 2 dan hasilnya sebagai berikut :

$$
\begin{aligned}
P & =\sqrt{3} \times V \times I \times \operatorname{Cos} \varphi \\
& =\sqrt{3} \times 387 \times 0,987 \times 0,5 \\
& =330,794 \mathrm{Watt} \\
& =0,330 \mathrm{~kW}
\end{aligned}
$$

Untuk menentukan pemakaian energi listrik selama 1 (satu) jam dari motor induksi tiga phasa sebagai kipas angin sebagai berikut :

$$
\begin{aligned}
W & =0,330 \mathrm{~kW} \times 1 \mathrm{jam} \\
& =0,330 \mathrm{kWh}
\end{aligned}
$$

Pemakaian selama satu (1) jam dalam sehari :

$$
\begin{aligned}
\text { Biaya energi listrik } & =0,330 \mathrm{~kW} \times 1 \mathrm{jam} \times \text { Rp.1.352,- } \\
& =R p .446,16
\end{aligned}
$$

Untuk pemakaian satu bulan maka biaya energi listrik adalah :

30 hari $x$ Rp. $446,16=$ Rp. $13.384,8$

Energi listrik pada motor induksi tiga phasa menggunakan VSD adalah sebesar 0,330 kW. Hubungan antara waktu dengan daya motor induksi tiga phasa menggunakan VSD seperti pada gambar 9. Dari gambar terlihat bahwa dengan penggunaan VSD tiga phasa maka daya dari motor induksi tiga phasa mendekati konstan bila dibandingkan dengan motor induksi tiga phasa tanpa VSD. 


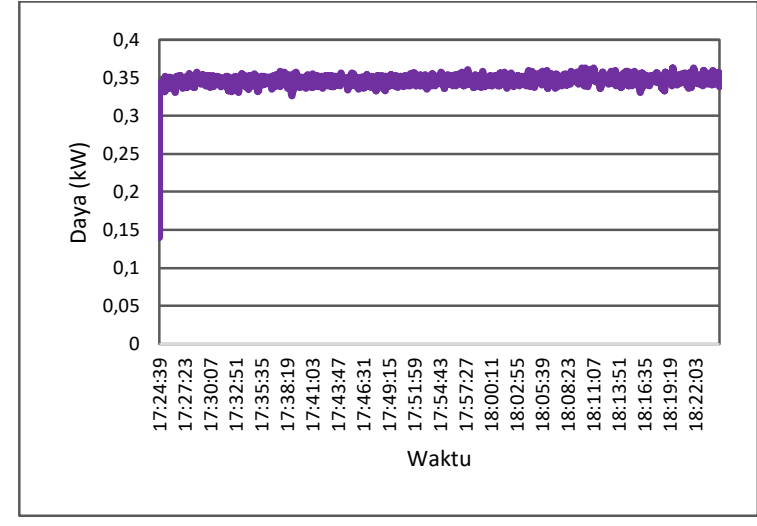

Gambar 9 Grafik daya motor induksi tiga phasa menggunakan VSD

Grafik penggunaan energi listrik dari motor induksi tiga phasa menggunakan VSD seperti terlihat pada gambar 10, dimana dalam rentang waktu 1 jam penggunaan energi listrik sebesar $0,330 \mathrm{kWh}$.



Gambar 10. Grafik pemakaian energi listrik pada motor induksi tiga phasa menggunakan VSD

Bentuk grafik perbandingan penggunaan energi listrik dari motor induksi tiga phasa tanpa VSD dan menggunakan VSD seperti pada gambar 11.

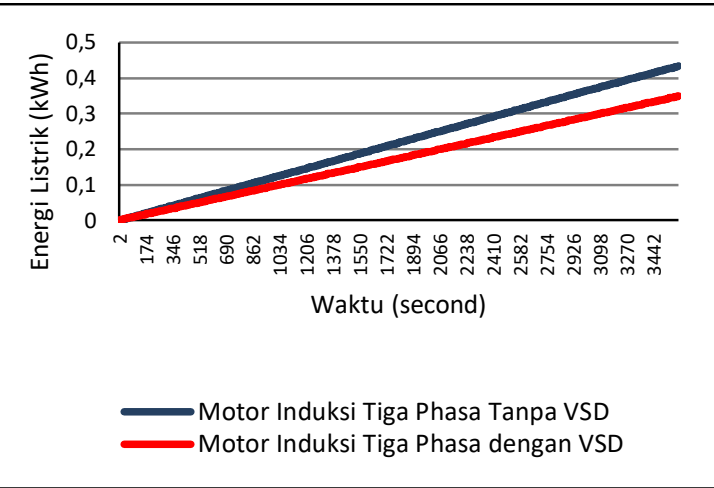

Gambar 11. Grafik perbandingan pemakaian energi listrik saat motor induksi tiga phasa beroperasi tanpa VSD dan menggunakan VSD
Dari gambar 11 terlihat bahwa penggunaan energi listrik motor induksi tiga phasa dari awal starting sampai beroperasi dalam waktu 1 jam, penggunaan energi listrik motor induksi tanpa VSD lebih tinggi dibandingkan dengan menggunakan VSD.

Hasil pengukuran memperlihatkan bahwa penghematan energi listrik yang diperoleh untuk motor induksi tiga phasa tanpa VSD dan menggunakan VSD adalah sebagai berikut :

Penghematan energi listrik selama satu (1) jam dalam sehari.

Penghema tan energi listrik:

$$
=\frac{0,479-0,330 \mathrm{kWh}}{0,479} \times 100 \%=31,10 \%
$$

atau bila dihitung dalam biaya sebesar Rp. 201,448 dalam satu hari dan Rp. 6.043,44 dalam satu (1) bulan. Adapun perbandingan penggunaan energi listrik dari tabel 1 dan tabel 2 adalah seperti pada gambar 12 selama pemakaian satu (1) jam. Dari gambar 12 terlihat bahwa penggunaan energi listrik menggunakan VSD lebih rendah sebesar $0,149 \mathrm{kWh}$ dibandingkan dengan motor induksi tanpa VSD atau penghematan energi listrik sebesar $31,10 \%$.

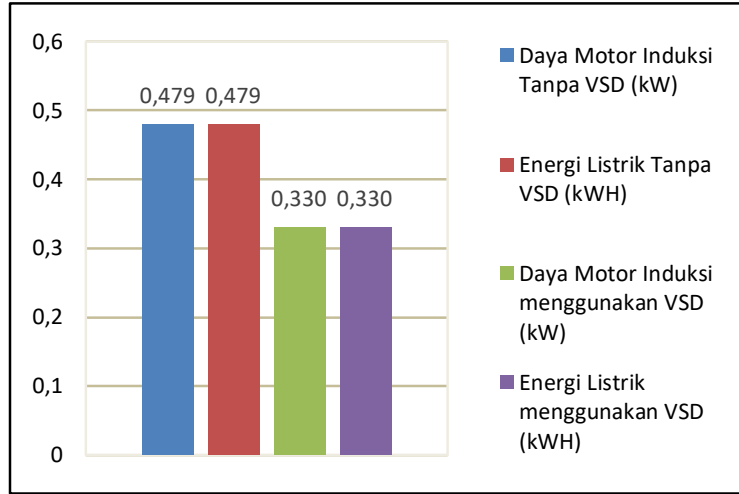

Gambar 12. Grafik perbandingan pemakaian energi listrik pada motor induksi tanpa VSD dan menggunakan VSD

\section{KESIMPULAN}

1. Motor induksi tiga phasa bila dioperasikan tanpa menggunakan VSD diperoleh daya sebesar 0,479 $\mathrm{kW}$ dengan energi listrik sebesar $0,479 \mathrm{kWH}$ dan motor induksi menggunakan VSD diperoleh daya sebesar $0,330 \mathrm{~kW}$ dengan energi listrik sebesar $0,330 \mathrm{kWh}$.

2. Perbandingan penggunaan energi listrik motor induksi tiga phasa menggunakan VSD lebih rendah sebesar $0,149 \mathrm{kWh}$ dibandingkan tanpa VSD dengan penghematan energi listrik sebesar 31,10\% atau sebesar Rp. 6.043,44 dalam satu bulan. 


\section{DAFTAR PUSTAKA}

[1] A. Kale, N.R. Kamdi, M.P. Kale, P.A.A. Yeotikar, a Review Paper on Variable Frequency Drive, Int. Res. J. Eng. Technol. 4 (2017) https://irjet.net/archives/V4/i1/IRJETV4I1229.pdf.

[2] Atmam, E. Zondra, Zulvahri, Analisis Penggunaan Energi Listrik Pada Motor Induksi Satu Phasa dengan Menggunakan Inverter, SainETIn. 1 (2017) 1-8; ISSN 2548-9445.

[3] L. Alberti, N. Bianchi, S. Bolognani, Finite element modeling of induction motor for variable speed drives, Electr. Mach. 2008. ICEM 2008. 18th Int. Conf. (2008) 1-5. doi:10.1109/ICELMACH.2008.4799964.

[4] I.A. Malik, N. Hariyanto, Analisis Penghematan Energi Motor Listrik di PT . X, J. Reka Elkomika. 1 (2013) 281-294.

[5] H. Haryanto, Pembuatan Modul Inverter sebagai Kendali Kecepatan Putaran Motor Induksi, J. Rekayasa. 4 (2011) 9-20.
[6] F.O. Enemuoh, E.E. Okafor, J.C. Onuegbu, V.N. Agu, Modelling, Simulation and Performance Analysis of A Variable Frequency Drive in Speed Control Of Induction Motor, 3 (2013) 36-41.

[7] Gomgom, I. Effendi, Penerapan Variable Frequency Drive Pada Motor Fuel Screw Feeder Untuk Bahan Bakar Pada Sistem Boiler, J. Desiminasi Teknol. 2 (2014) 50-59.

[8] Y. Badruzzaman, Sistem Monitoring Kendali Motor Induksi Tiga Fasa Dengan Variable Speed Drive Berbasis Plc Dan Scada, J. ORBITH. 11 (2015) 147-152.

[9] R.S. Bharj, S. Kumar, Experimental study of power reduction from cold storage by using VFD, Int. J. Res. Manag. Sci. Technol. (E-ISSN 2321-3264). 4 (2016) 1-5.

[10] M.H. Rashid, Elektronika Daya (Power Electronics: Circuits, Devices, And Application 2ND ED) Edisi Bahasa Indesia, Jilid 1, 1st ed., Prenhallindo, Jakarta, 1999.

[11] Daniel W. Hart, Power Electronics, McGrawHill, Americas, New York, NY 10020, 2011. 